\title{
The leader strategy in improving performance of navy human resources
}

\author{
Widodo ${ }^{1,}{ }^{*}$, Adi Bandono ${ }^{2}$ and Okol Sri Suharyo ${ }^{2}$ \\ ${ }^{1}$ Indonesia Defense University, UNHAN Jakarta Indonesia. \\ ${ }^{2}$ Indonesia Naval Technology College, STTAL Surabaya Indonesia.
}

Global Journal of Engineering and Technology Advances, 2021, 09(03), 023-030

Publication history: Received on 26 October 2021; revised on 02 December 2021; accepted on 04 December 2021

Article DOI: https://doi.org/10.30574/gjeta.2021.9.3.0157

\begin{abstract}
Nowadays the Indonesian Navy is considered to have succeeded in strengthening its role in carrying out the development of a world-class marine defense force and has also received recognition from various countries in the world. However, there are still many problems regarding improving the performance of human resources in the Navy organization. This study aims to determine the strategy of the Navy Leaders in improving the quality of competent human resources in their fields. Furthermore, the research objectives can be detailed again and are more operational in nature, namely a). Formulating a strategy for the leader of the Navy to solve the problem of inequality in the number of personnel with existing positions, especially in the lieutenant colonel and colonel strata until 2024 and b). Determining the strategy of the leader of the Navy in solving problems has not created a synergy between the functions of education, use, and maintenance so that it hinders the development of personnel. The method used in this study is a qualitative approach based on direct observation analysis, expert interviews, and literature study. The qualitative approach assumes that human resources are active resources, therefore the qualitative approach aims to understand the object and make explorations. The strategy results obtained are the implementation of competency-based personnel development policies, empowerment of the Navy Personnel Assessment center, carrying out "Superior Job Performer" activities, conducting Competency Based Interview (CBI) training and developing "Integrated Personnel Information System", and implementing the second policy careers for personnel who are not elected to certain positions. Furthermore, synergize between the functions of education, use, and maintenance of personnel for continuous personnel development.
\end{abstract}

Keywords: Leader Strategy; Human Resources Performance; Indonesia Navy

\section{Introduction}

The Indonesian Navy is currently considered to have succeeded in strengthening its role in carrying out the development of a world-class marine defense force and has also received recognition from various countries in the world. This success has been achieved by the Indonesian Navy since the 1950s until now, while at the same time maintaining its status as the strongest navy in Southeast Asia, even in budget constraints and a significant increase in the naval power of other countries.

This condition is very encouraging, considering that the public leadership of the Indonesian Navy in the international arena is truly recognized and taken into account so that it is also of strategic value for the Indonesian nation in safeguarding national interests. Marsetio (2014) once presented an analysis that by having a world-class navy, the benefits that can be obtained for the Indonesian people, among others, can be: increasing the deterrence effect to discourage other countries from direct and open confrontation; building and earning the trust of the international community; improve the bargaining position of the state in various efforts to resolve regional and international

\footnotetext{
* Corresponding author: Widodo

Indonesia Defense University, UNHAN Jakarta Indonesia.
} 
problems as an integral part of the Government's diplomacy and the implementation of foreign policy, and safeguarding national interests inside and outside the region.

However, it does not mean that with the success of these achievements, the Indonesian Navy is not facing quite complicated problems in the field of human resources. The problems faced in the field of human resources which are expected to hinder the achievement of the development of Naval human resources towards the new paradigm of the world-class Navy include: (1) There is an imbalance in the number of personnel with existing positions, especially at the lieutenant colonel and colonel strata until 2024 This can have an impact on "demotivating" officers who cannot enter the Colonel position, because of the tight selection. (2) There has not been a synergy between the functions of education, use, and maintenance so that it hinders the development of personnel. After completing education to improve their competence, personnel is faced with a mismatch between their competence and the field of assignment in the field. In addition, the function of personnel maintenance, especially those assigned to remote areas, is not given much attention, resulting in a decrease in the motivation of personnel to work.

The two problems mentioned above must be resolved immediately so that a wise solution can be realized. Solving protracted human resources problems can harm both the macro and micro performance of the Navy's organization in carrying out its main tasks. Given the urgency of solving these three problems and how the strategy taken by the Navy Leaders, the author intends to discuss them in a short paper entitled "Leader's Strategy to improve HR in the Navy".

From the background of the problem, the problem can be formulated as follows: "what is the strategy of the Navy Leaders in improving the quality of human resources in the Navy?" The formulation of the problem can be further broken down into a more operational problem formulation, including:

- What is the strategy of the leader of the Navy in solving the problem of inequality in the number of personnel with existing positions, especially in the lieutenant colonel and colonel strata until 2024?

- How is the strategy of the leader of the Navy in solving the problem that there is no synergy between the functions of education, use, and maintenance that hinders personnel development?

The purpose of writing this paper is to get an overview of the strategies adopted by the Navy Leaders in improving the quality of human resources within the Navy.

\section{Material and methods}

\subsection{Strategy Theory}

In everyday conversation, strategy can be interpreted as a way, namely a way to achieve a goal. According to Haming and Jamuddin (2007) strategy comes from the Greek strategies with the root word meaning military status and meaning leading. So that the notion of strategy is the translation of the organization's vision into the formulation of long-term policies to serve as guidelines in moving the organization to the goals that have been planned consistently and to make relevant decisions regarding the empowerment of the organization's resources. Griffin in Sule and Saefullah (2008) defines strategy as a comprehensive plan to achieve organizational goals. Not only achieving but the strategy is also intended to maintain the survival of the organization in the environment in which the organization carries out its activities. According to Marrus (2002) strategy is defined as a process of determining the plan of top leaders that focuses on the long-term goals of the organization, accompanied by the preparation of a method or effort on how to achieve these goals.

From the description above, it can be concluded that strategy is a process carried out by the organization to maintain the survival of the organization in the long term, both against changes in the internal or external environment of the organization. Strategy formulation is the process of preparing the next steps to build the organization's vision and mission, setting strategic and organizational financial goals, and designing strategies to achieve these goals to provide the best customer value. Hariadi (2005) suggests that there are several steps that organizations need to take in formulating strategies, namely:

- Identify the environment that will be entered by the organization in the future and determine the organization's mission to achieve the vision aspired to in that environment.

- Conduct internal and external environmental analysis to measure strengths and weaknesses as well as opportunities and threats that will be faced by the organization in carrying out its mission.

- Formulate the key success factors of the designed strategies based on the previous analysis. 
- Determine measurable goals and targets, evaluate various alternative strategies by considering the available resources and external conditions faced.

- Choose the most suitable strategy to achieve short-term and long-term goals.

In the context of writing this paper, what is meant by strategy is the method or steps taken by the Navy leaders in improving the quality of human resources within the Navy.

\subsection{Leadership Theory}

Leadership is defined as a process where a person can influence each individual in a group to achieve the desired goals (Northouse, 2001). Talking about leadership, especially in the Indonesian Navy, most people would think that the type of leadership applied in the Indonesian Navy is an authoritarian type of leadership. The characteristic of authoritarian leadership is that there are orders from superiors to subordinates that cannot be rejected or negotiated. This view is not wrong, but it is also not true. The main type of military leadership applied in the Indonesian Navy adheres to many variations of leadership types. Broadly speaking, there are four assignment areas with different types of leadership, including leadership in the Fleet, leadership in the Marines, leadership in the Base, and leadership in educational institutions. Leadership in the Fleet and Marines is more dominant in applying authoritarian leadership because there is a place for warships and troops to be ready to depart for war. Meanwhile, leadership in Pangkalan is colored more by democratic leadership, considering that its area of duty is more related to the wider community. The leadership in educational institutions is more dominant in applying transformational leadership.

What about the type of leadership that is applied to solving personnel problems faced by the Navy. Solving personnel problems in the Navy is more dominant in applying the transformational leadership type approach as applied in educational institutions. This type of leadership according to Hesselbein and Cohen (1999) places the leader as a very vital role holder for the effective management of an organization. Robbins and Coulter (2007) argue that people who have transformational leadership are those who can encourage, stimulate and inspire followers to achieve the expected results.

The success of transformational leadership practices in supporting the performance of an organization so that it can achieve the best performance is because transformational leadership has very adaptive characteristics and can face the development of a globalized era with all the complexity of its problems. According to Hamel and Prihalad (1995), transformational leadership has been able to meet the needs of local, regional, and world markets.

The initial concept of transformational leadership has been formulated by Burn et al (1978) which explains that transformational leadership is a process, between leaders and followers raise each other to a high level of morality and motivation. One of the situational factors that will influence the effectiveness of leadership in the next decade is the relationship between leaders and their followers. The essence of the relationship is the interaction between individuals with different motivations and power potentials, including skills, to achieve common goals.

Bass and Avalio (1994) suggest that followers of transformational leaders place high trust, admiration, loyalty, and respect for their leaders so that they are motivated to do more than what was initially expected. Transformational leadership can be viewed both as a process of influencing at the micro-level between individuals and influencing at the macro level in mobilizing power to change social systems and institutions. Transformational leadership is very suitable to be applied during the era of globalization which is always characterized by very fast changes and accompanied by uncertainty. Its influence is enormous for the life of a nation and state. Globalization in the economic field to technological innovation, especially in the field of telecommunications, encourages the pulse of change in human life. John Naisbitt (2000) argues that the telecommunications revolution has been the driving force that instantly created the world economy and made its parts smaller and stronger.

Leaders must promote change by creating a vision. Leaders must have a clear understanding of the strategic goals for their organization, identify the actions needed to achieve those goals, and analyze the existing organizational ideology. This has been practiced in research by Bandono (2020) with the topic The Application Model of Naval Collaboration Flexible Learning (NCFL) in the Indonesian Naval Technology College. The type of leadership needed to change culture is transformational leadership because cultural change requires a lot of energy and commitment to achieve results. An understanding of culture and how to change it is an important skill of leaders who seek to achieve strategic outcomes in the management of an institution. 


\subsection{Performance Management Theory}

According to G. R. Terry (2003), management is defined as a typical process consisting of planning, organizing, implementing, and monitoring carried out to determine and achieve goals by utilizing human resources and other resources. According to James A. F. Stoner (1996), management is defined as the process of planning, organizing, leading, and supervising the efforts (efforts) of organizational members and using all organizational resources to achieve the goals that have been set. So management is the process of using organizational resources by using other people to achieve organizational goals effectively and efficiently, by carrying out management functions such as planning, organizing, directing and implementing, and monitoring.

Meanwhile, the word performance is an abbreviation of work energy kinetics whose equivalent in English is performance, which is often translated into Indonesian with the word performance. Definition of Performance according to some experts are as follows:

- Performance is a set of results achieved and refers to the act of achieving and carrying out a requested job (Stolovitch and Keeps, 1992)

- Performance is one of the total collections of work that exists in workers (Griffin, 1987)

- Performance is a function of motivation and ability. To complete a task or job a person must have a certain degree of willingness and level of ability. A person's willingness and skills are not effective enough to do something without a clear understanding of what will be done and how to do it (Hersey and Blanchard, 1993).

- Performance refers to the level of success in carrying out tasks and the ability to achieve the goals that have been set. Performance is declared good and successful if the desired goals can be achieved properly (Gibson, Donelly, and Ivancevich, 2000).

From the two words management and performance, when combined into one new word, namely Performance Management, there are several definitions put forward by experts, as follows:

- Performance management as a communication process that is carried out continuously in partnership between employees and their direct superiors. This communication process includes activities to build clear expectations and understanding of the work to be done (Bacal, 1994).

- Performance management as a means to get better results from organizations, teams, and individuals by understanding and managing performance within a framework of agreed goals, standards, and attribute requirements (Armstrong, 2004).

- Performance management is a management style that is open communication between managers and employees regarding goal setting, providing feedback from managers to employees, and vice versa (Schwartz, 1999).

- Performance management is the basis and driving force behind all organizational decisions, efforts, and resource allocation (Costello, 1994).

By taking into account the opinions of experts, it can be concluded that performance management is a management style in managing performance-oriented resources that carries out an open and sustainable communication process by creating a shared vision and strategic and integrated approach as a driving force to achieve organizational goals. Performance management is a process designed to improve the performance of organizations, groups, and individuals driven by managers as well as educational and teaching roles, especially in Navy organizations. This is in line with research conducted by Bandono (2020) with the theme The Effect of The Learning Model Naval Collaboration Flexible Learning (NCFL) on The Quality of Education Outcomes.

\subsection{Research Approach Method}

The method approach used in this paper is a qualitative writing approach. The qualitative approach assumes that humans are active creatures, therefore the qualitative approach aims to understand the object and make explorations (Bandono et al, 2020). The qualitative approach describes the exploration of the object of writing through procedures and non-numerical data. Qualitative writing in this paper intends to dig up information in a participatory manner. The information obtained in this paper will then be described as participatory meaning that describes the existing conditions. Therefore, the data generated from this qualitative writing is descriptive in the form of written or spoken words from people or from the behavior to be observed. In this paper, a qualitative writing approach will be directed at an individual who will be observed as a whole following the problems that arise. 


\section{Results and discussion}

\subsection{Analysis The Number of Personnel with positions in the Lieutenant Colonel and Colonel until 2024.}

With time, it is estimated that in 2024, the Indonesian Navy organization will face big problems, where many personnel is not accommodated in the positions of lieutenant colonels and colonels. The description of the condition of the Indonesian Navy personnel with the rank of colonel until 2024 has reached $+/-160 \%$ (Naval Headquarters, 2015). Under these conditions, personnel at the level of lieutenant-colonel will have difficulty promoting to colonel due to the limited number of available colonel positions. If such conditions occur, it is estimated that there will be demotivation in several Indonesian Navy officers who will later be unable to enter the colonel position, as a result of tight selection and increased subjectivity.

For the long-term sustainability of the Navy's organization, the Navy's leadership strategies that need to be taken to overcome the imbalance in the number of personnel with positions in the lieutenant colonel and colonel strata include:

- $\quad$ Enforcement of competency-based personnel development policy through the implementation of a competency-based selection system. Only officers who have the competencies needed and expected by the organization can be promoted to colonel positions.

- $\quad$ To support the competency-based personnel development policy so that it runs optimally, it is necessary to establish a Navy Personnel Assessment Center. This institution, apart from optimizing the Personnel Development selection system, can also be directed to answer the demands for bureaucratic reform in the area of structuring the human resources of the State Apparatus which is nationally promoted by the Government.

- $\quad$ Carry out "Superior Job Performer" activities, to produce specifications for personnel capabilities obtained from the best personnel capabilities that already exist in the organization at this time.

- $\quad$ Conducting Competency Based Interview (CBI) training for personnel who will later serve as assessors of the Indonesian Navy Personnel Assessment Center. The assessors involved are a combination of HR experts in the Navy Psychology Service, Corps Trustees, Professional Coaches, Users (Personnel Development), and others as needed so that the combination is expected to produce a more comprehensive decision.

- Develop an "Integrated Personnel Information System" that has been running so far to become an information system that supports decision-making at the Indonesian Navy Personnel Assessment Center. Through this information system, personnel data becomes valid and always updated, and displays high objectivity.

- Implementing a second career policy for personnel who are not elected to group IV positions or who are prepared to occupy positions outside the military structure.

\subsection{Strengthening Synergy between the Functions of Education, Use, and Management of Personnel}

The achievement of the professionalism of the Indonesian Navy personnel can be realized through the implementation of the functions of personnel development synergistically and sustainably. From the results of the evaluation of the implementation of Personnel Development within the Indonesian Navy, it can be identified that the problems that often occur are caused by the lack of synergy in the implementation of the functions of education, use, and maintenance so that it can hinder the development of personnel on a macro basis.

The lack of synergy between the functions of education, use, and maintenance, can be described as follows:

- Lack of fulfillment of the main maintenance function in remote areas or outside Java which results in a decrease in personnel motivation so that their performance in carrying out the use function is not as expected. The factor of the lack of welfare obtained by personnel, the difficulty of transportation and communication, and the lack of attention from the government, both central and local, can lead to a degradation of motivation to perform the best and optimally possible.

- Policies on the education function at the implementation level often experience deviations. For example, now many personnel are sent to school to take undergraduate academic degrees, master's, and doctor. Naval Education Office as the educator of education has determined the type of discipline taken must be following the needs of the organization. However, in its implementation, the average discipline taken is not following the needs of the organization, so that when returning to assignment it cannot make a positive contribution to improving organizational performance. Another example, the Indonesian Navy has provided an opportunity for selected personnel to participate in Military General Development Education, but at the time of promotion, they were unable to compete with personnel who were not selected to participate in Military General Development Education. 
The condition of lack of synergy can hamper the personnel development system within the Indonesian Navy. The strategy of the Navy Leaders to synergize the functions of personnel development that can be taken, among others, includes:

- In the education function, it is necessary to rearrange undergraduate education so that it is adjusted to the strata of rank, competence, and interests that are synergized with the needs of the organization. Optimizing education is directed following the vision, mission, and goals of the organization, as well as the Navy's Force Development Planning. Optimization of the education function must cover 8 aspects of education (Education Patterns and Structures, Ten Educational Components, Educational Control, and Operational Devices, Education Implementation, Education Development, Education Validation, Educational Environment, Level of Authority and Responsibility) and 10 educational components (Education Curriculum). Instruction Packages, Educators, Education Personnel, Students, Education Evaluation, Learning Methods, Education Facilities, Instructional Tools and Instructional Assistance Tools, Budget) as a complete Indonesian Navy education system.

- In the use function, competency-based personnel development policies are implemented through the application of a competency-based selection system. Only officers who have the competencies required by the organization can be promoted to certain positions required by the organization. The Indonesian Navy's Personnel Assessment Center is empowered to optimize the Personnel Development selection system and to respond to demands for bureaucratic reform. To get personnel who excel, it is necessary to hold a "Superior Job Performer", so that leadership talent can be fostered through transformational leadership that is already running in the organization today.

- In the maintenance function increased attention and welfare of personnel, especially those placed in remote, frontier, and outermost areas so that the work motivation of personnel there remains high. The Navy needs to lobby with the Central Government (Ministry of Home Affairs) and Regional (Provincial and City/Regency) so that they pay attention to the development of remote, frontier, and outermost areas so that the economy of the people there can get better.

\section{Conclusion}

- The Navy leadership strategies that need to be taken to overcome the gap in the number of personnel with positions that exist in the lieutenant colonel and colonel strata, include: implementing competency-based personnel development policies, empowering the Navy Personnel Assessment Center, carrying out "Superior Job" activities. Performer", conducted Competency Based Interview (CBI) training for prospective assessors at the Navy Personnel Assessment Center, developed an "Integrated Personnel Information System", and implemented a second career policy for personnel who were not selected for class IV positions or who were prepared to occupy positions. outside the Military structure.

- The strategies of the Navy Leaders to synergize the functions of personnel development that can be taken include:

- In the education function, it is necessary to rearrange the undergraduate education attended by Navy personnel so that it is adjusted to the strata of rank, competence, and interests that are synergized with the needs of the organization.

○ In the use function, competency-based personnel development policies are implemented through the application of a competency-based selection system. To get personnel who excel, it is necessary to hold a "Superior Job Performer", so that leadership talent can be fostered through transformational leadership that is already running in the organization today.

- In the maintenance function, an increase in the attention and welfare of personnel, especially those placed in remote, front and outer areas, is implemented so that the motivation to work of the personnel there remains high.

\section{Suggestion}

For the strategy of the Indonesia Navy leaders in improving the quality of human resources to achieve success, the following suggestions are submitted:

- The need for a joint commitment in managing the Indonesian Navy's human resources, because the majority of human resources problems that occur are due to a lack of commitment in making personnel decisions.

- The Indonesia Navy personnel development system, in general, has implemented the principles of human resources management on an international scale, but the special character of the Indonesia Navy Personnel Management needs to be maintained as an identity of excellence. 
- The Indonesian Navy needs to increase collaboration networks with other ministries, and other private companies, to find alternative new second career positions for personnel who are not selected for group IV positions or who are prepared to occupy positions outside the Indonesia Military structure.

\section{Compliance with ethical standards}

\section{Acknowledgments}

The authors greatly acknowledge the support from the Indonesia Defense University, UNHAN Jakarta, and Indonesia Naval Technology College, STTAL Surabaya Indonesia for providing the necessary resources to carry out this research work. The authors are also grateful to the anonymous reviewers and journal editorial board for their many insightful comments, which have significantly improved this article.

\section{Disclosure of conflict of interest}

The authors declared no potential conflicts of interest concerning the research, authorship, and/or publication of this article.

\section{References}

[1] Amstrong M, Baron A. Performance management. Yogyakarta: Tugu Publisher. 2004.

[2] Bandono A, Bastari A, Suharyo OS. Effectiveness Naval Collaboration Flexible Learning (NCFL) Model in Increasing Learning Outcomes The Indonesian Naval Technology College. International Journal of Progressive Sciences and Technologies. 2020; 23(2): 434-442.

[3] Bandono A. The Application Model of Naval Collaboration FlexibleLearning (NCFL) in the Indonesian Naval Technology College: A Case Study. International Journal of Progressive Sciences and Technologies (IJPSAT). 2020; 23(2): 498-505.

[4] Bandono A. The Effect of The Learning Model Naval Collaboration Flexible Learning (NCFL) On The Quality of Education Outcomes: An Innovative approach to Islamic Religious Education In The Naval College Of Technology. Halaqa: Islamic Education Journal. 2020; 4(2): 160-190.

[5] Bass BM, Avolio BJ. (Eds.). Improving organizational effectiveness through transformational leadership. Sage. 1994.

[6] Bransford J, Stevens R, Schwartz D, Meltzoff A, Pea R, Roschelle J, Sabelli N. Learning theories and education: Toward a decade of synergy. 2006.

[7] Belias D, Koustelios A. The impact of leadership and change management strategy on organizational culture. European Scientific Journal. 2014; 10(7).

[8] Burn. Leadership Organizational, Englewood Cliffs, N.J. Prentice Hall Inc. 1978.

[9] Costello S. Effective performance management. McGraw-Hill. 1993.

[10] Gibson, Donnelly. Ivancevich. Struktur Proses Perilaku Organisasi, Jilid I Erlangga, Jakarta. 2000.

[11] Griffin RW. Management, Second Edition, Boston: Houghton Mifflin Press. 1987.

[12] Hariadi B. Strategi Manajemen Jakarta. 2005.

[13] Hall J, Johnson S, Wysocki A, Kepner K. Transformational leadership: The transformation of managers and associates. EDIS. 2002; (2).

[14] Hersey P, Blanchard K. Manajemen Perilaku Organisasi; Pendayagunaan Sumberdaya Manusia Edisi Keempat. 1992.

[15] Naisbit, John. Global Paradox, Jakarta: Binarupa Aksara. 2000.

[16] Marsetio. TNI Angkatan Laut Berkelas Dunia, Jakarta: Mabesal. 2014.

[17] Mabesal. Paparan Bidang Personel, Apel Komandan Satuan TNI AL 2015 dan Olah Yuda Renstra Tahun 2016, tanggal 16 Januari 2015. 
[18] Marrus SK. Building the strategic plan: Find, analyze, and present the right information. John Wiley \& Sons Incorporated. 1984.

[19] Northouse PG. Leadership: Theory and practice. Sage publications. 2021.

[20] Robbins SP, Coulter M. Principles of management. Translated by Seyyed Mohammad Arabi and Mohammed Ali Hamid Rafiee and Behrouz Asrari Ershad, Fourth Edition, Tehran: Office of Cultural Studies. 2007.

[21] Stoner AF, Freeman RE, Gilbert DR. Manajemen Edisi Bahasa Indonesia. PT. Prenhallindo. Jakarta. 1996.

[22] Stolovitch HD, Keeps EJ. Handbook of human performance technology: A comprehensive guide for analyzing and solving performance problems in organizations. Pfeiffer. 1992.

[23] Sule ET, Saefullah K. Introduction to Management (Pengantar Manajemen). 2008.

[24] Terry RG. Principles of Management, Richard D. Irwin, Inc, Home Wood, Illinois. 2003. 